\title{
International Committee on Systematic Bacteriology Subcommittee on the Taxonomy of Phototrophic Bacteria
}

Minutes of the Meeting, 24 July 1991, Amherst, Mass.

Session 1. Closed meeting.

Minute 1. Call to order. The meeting was called to order by the chairman, H. G. Trüper, at 8:00 p.m. on 24 July 1991.

Minute 2. Record of attendance. The members present were R. W. Castenholz (Eugene, Oreg.), V. M. Gorlenko (Moscow, Russia), B. V. Gromov (St. Petersburg, Russia), J. F. Imhoff (Bonn, Germany), E. N. Kondratieva (Moscow, Russia), M. T. Madigan (Carbondale, Ill.), R. Rippka (Paris, France), H. G. Trüper (Bonn, Germany), and J. B. Waterbury (Woods Hole, Mass.). Apologies were received from E. I. Friedmann, J. Komarek, P. A. Roger, J. Weckesser, and B. A. Whitton.

Minute 3. Minutes of previous meeting. The minutes of the meeting held in Manchester, United Kingdom, on 5 September 1986 were approved.

Minute 4. Chairman's report. Since the attempt to assemble the subcommittee at the International Union of Microbiological Societies congress in Osaka, Japan, in 1990 failed, this meeting is the first meeting since 1986. Since that time the subcommittee has not had a secretary. The election of a new chairman is overdue. As H. G. Trüper became chairman of the International Committee on Systematic Bacteriology in 1990 in Osaka, he will resign as chairman of the subcommittee after this meeting.

Minute 5. Changes in membership. T. A. Hansen (Haren, The Netherlands), N. Pfennig, (Konstanz, Germany), and W. T. Stam (Haren, The Netherlands) have resigned by submitting letters to the chairman. The subcommittee expresses its gratitude to them for their fruitful cooperation. As several other members have not answered letters from the chairman since at least 1982, the subcommittee unanimously decided to dissolve and immediately reconstitute itself with the members present and with $\mathbf{H}$. G. Trüper as acting chairman. The subcommittee unanimously decided that E. I. Friedmann, R. L. Gherna, J. Korn arek, P. Roger, J. Weckesser, and $\mathrm{B}$. Whitton will continue as members. It also elected unanimously as new members P. Caumette (Arcachon, France), A. Oren (Jerusalem, Israel), S. Ventura (alternate, L. Giovannetti) (Firenze, Italy), and A. Wilmotte (Antwerp, Belgium).

Minute 6. Election of officers. For chairman, J. F. Imhoff was proposed and was elected unanimously. For secretary, M. T. Madigan was proposed and was elected unanimously. The new officers will assume office after this meeting.

Minute 7. Scope of the subcommittee. The subcommittee decided that it will be concerned with all chlorophyll- or bacteriochlorophyll-containing phototrophic prokaryotes.
Minute 8. Adjournment. The meeting was adjourned at 8:35 p.m. on 24 July 1991.

\section{Session 2. Open meeting.}

Minute 9. Call to order. The meeting was called to order by the acting chairman at 8:40 p.m. on 24 July 1991. It was attended by the same members as the closed meeting. New members L. Giovanetti and A. Oren also attended. C. Abellá, M. Cusanovich, F. Garcia-Pickel, L. Hoffmann, T. E. Meyer, and J. Overmann were present as guests.

Minute 10. Reports on new developments. J. B. Waterbury described new findings on the phylogeny of cyanobacteria. The phylogenetically coherent groups are the heterocystous forms (representing one order rather than two) and the pleurocapsalean cyanobacteria (excluding the budding forms). The unicellular cyanobacteria and the filamentous cyanobacteria do not form phylogenetically coherent groups. The prochlorophytes do not form a separate coherent group but belong to different groups of cyanobacteria; they are "just unusual"' cyanobacteria. J. F. Imhoff reported on the following newly described phototrophic proteobacteria: Rhodopseudomonas julia, Rhodopseudomonas cryptolactis, Rhodopseudomonas rosea, Rhodospirillum centenum, Erythromicrobium sibiricum, Erythromicrobium ursincola, Erythromicrobium ezovicum, Erythromicrobium ramosum, Erythromicrobium hydrolyticum, Roseobacter litoralis, Roseobacter denitrificans, Roseococcus thiosulfatophilus, Ectothiorhodospira marismortui, Chromatium salexigens, Chromatium tepidum, Thiocapsa halophila, Amoebobacter pedioformis, and Amoebobacter purpureus. M. T. Madigan reported on two newly described members of the family Chlorobiaceae, Chlorobium tepidum and Pelodictyon phaeoclathratiforme. R. W. Castenholz and E. N. Kondratieva described recent research on the family Chloroflexaceae, and M. T. Madigan reported on the heliobacteria Heliobacterium chlorum, Heliobacterium gestii, Heliobacterium fasciculum, and Heliobacillus mobilis.

Minute 11. Discussion. The reliability of rRNA sequence data compared with other chemotaxonomic and phenotypic data was discussed.

Minute 12. Adjournment. The meeting was closed at 9:45 p.m. on 24 July 1991.

Hans G. Trüper, Chairman 